\title{
Analysis of development of gifted students in elementary school
}

\author{
Aldo Redho Syam, Syarifan Nurjan, Lilis Sumaryanti
}

Universitas Muhammadiyah Ponorogo aldoredho@umpo.ac.id

Submitted: 19-11-2020, Revised: 07-04-2021, Accepted: 24-05-2021

\begin{abstract}
This study aims to analyze the development of gifted student's elementary schools at MI Pesantren Anak Sholeh Baitul Qur'an Gontor Ponorogo. This research uses a descriptive, qualitative approach. Data comes from observations and interviews with the principal, teachers, guardians of students, and students. The data analysis technique used an interactive model (Miles and Huberman), while the data validity test used data triangulation. The results showed that the talent development of elementary school students was in line with the concept of the three rings Renzulli, where the characteristics of gifted students at MI Pesantren Anak Sholeh Baitul Qur'an Gontor. Santri showed above-average ability, commitment to task, enthusiasm, confidence, desire, exhibits high creativity such as fluency, flexibility and originality in thinking, openness to experience, curiosity, and courage to take steps.
\end{abstract}

Keywords: Basic education; Development; Giftedness; Students

\section{Introduction}

Every human being is born as an individual with different potentials, abilities, traits, or attitudes. Groups called unique talents are those who have a superior potential above the potential possessed by normal humans (Renzulli, 2016). Usually, they have a unique perspective from other humans. Prophet Muhammad said:

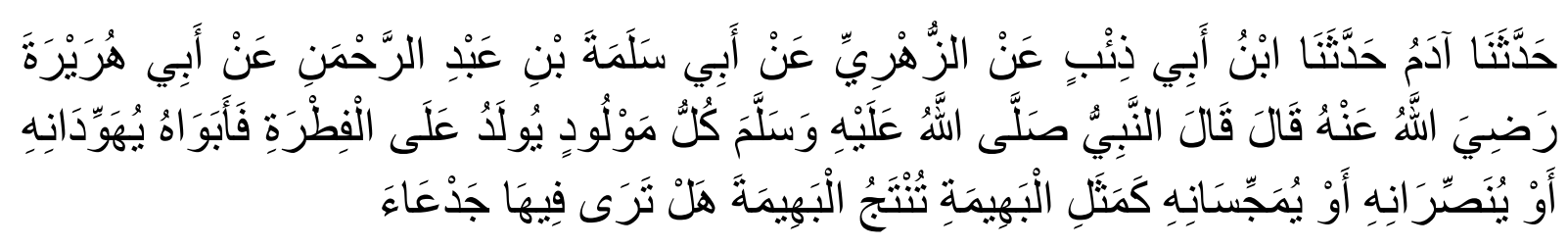

\section{Narrated Abu Huraira:}

The Prophet said, "Every child is born with a true faith of Islam (i.e. to worship none but Allah Alone) and his parents convert him to Judaism or Christianity or Magianism, as an animal delivers a perfect baby animal. Do you find it mutilated?" (Bukhori, Hadith Number 2296, 2011).

As social beings, gifted students are the same as other students, they experience growth and development which is influenced by nature, thoughts, attitudes, creativity, and relationships (Anggraini et al., 2020; Munandar, 2012). However, what distinguishes them from other gifted students is the students' goals, interests, and potential (Tresnawaty, 2015). This makes them need special attention from various parties, both family, school, and community (Yoenanto, 2012).

According to Klimecká (2020), the problems faced by gifted students are labeling problems, grading as numbers, underachievers, and self-concept problems. Student problems can raise expectations of ability, increase the mental burden and lead to frustration (Yaman \& Sökmez, 2020). Problems with gifted students, namely: problems with unrealistic career choices or unpopular career choices, relationships with teachers or peers, mismatched 
development and sometimes causing problems for themselves and their environment; and ideal figure (Hava et al., 2020).

If the problem is not getting immediate guidance and counseling, it will lead to inappropriate behavior that hinders the development of their potential talents (Lee \& Son, 2017; Sendayu \& Sunaryo, 2020). One of the guidance and counseling tasks is to help gifted students to overcome their problems (Aulia, 2020). Gifted students have abilities and interests in a wide variety of fields, making it difficult to determine which areas they will take seriously (Yaman \& Sökmez, 2020).

Gifted children are the same as other normal children who need a touch of guidance and counselling in dealing with all their problems (Rimonda et al., 2018). Gifted students are the same as other students who need help to maximize their potential for school achievement Zeidner \& Matthews (2017). According to Miller (2014), the help provided to gifted students is assisting individuals to achieve the self-understanding and self-direction needed to make maximum adjustments to schools, families, and communities. Assistance provided to gifted students is a process that involves a professional and tries to help others achieve selfunderstanding, make decisions, and solve problems (Laine \& Tirri, 2016; Pietrofesa et al., 1971).

We can know that the quality of a person is seen from the level of personality and potential (talents, interests, and abilities), so that gifted children also need programs that can develop their talents and potential (Syafril et al., 2020; Thahir \& Hidayat, 2020). This program differs from guidance and counseling based on the characteristics, needs, and problems faced by gifted children (Ersoy \& Uysal, 2019; Yaman \& Sökmez, 2020). This demands the sensitivity of the counselor or supervisor because of their unique needs (Ozcan \& Uzunboylu, 2019).

Guidance for basic education students can help them become independent, aware of their growth and development barriers, and allow them to open up so that they can develop themselves (Ozcan \& Uzunboylu, 2019), as happened in MI Pesantren Anak Sholeh Baitul Qur'an Gontor Ponorogo. There are five types of talents that Baitul Qur'an Gontor Ponorogo students have. The first talents are general intellectuals such as high academic achievement and intelligence; second, special academic talents, in the field of public speaking and qiraah al-Quran; third, leadership talent; fourth, talent in one field of music, tambourine, painting, dance, and singing; Fifth, psychomotor talents, namely drum band, futsal, swimming, gymnastics, and martial arts. Meanwhile, the talent for creative-productive thinking has not been found.

The principal is responsive in responding to the needs of students, responding to student problems, providing facilities, and counseling services to students who have hidden talents and high achievement. Therefore, the researcher wanted to conduct a developmental analysis of gifted children and wanted to find out how successful the teacher was in helping overcome the problems that students faced.

\section{Methods}

This study used a qualitative approach with a case study design (Ulfatin, 2015), to analyze the talents of primary education students at Madrasah Ibtidaiyah Pesantren Anak Sholeh Baitul Qur'an Gontor Ponorogo, based on facts and data obtained during field observations. The research location was the Islamic Boarding School for Children Sholeh Baitul Qur'an Gontor Ponorogo. The subjects in this study were the principal, teachers, guardians of students, and students. The researcher acts as a key instrument that must be present directly at the research location for primary data collection in qualitative research(Ulfatin, 2015). 
Data collection techniques using observation and interviews. Interviews with school principals, teachers, counselors, and students. These techniques are basic qualitative data collection techniques that aim to produce data descriptions in oral, written, and photographic forms that will provide an overview of behavior, observable features of the research object (Sugiyono, 2015). After the data is obtained, it is analyzed in stages, data analysis is carried out before entering the field, during the field, and after completing the field. Data analysis used in this study consisted of: data collection; data reduction; presentation of data; and conclusions (Miles et al., 2014).

\section{Results and Discussion}

Delving into the uniqueness of an individual is indeed fun, but if this is an analogy of a teacher figure who must identify the characteristics and abilities of his students well, then it is no longer a simple thing (Fadhli et al., 2019; Nurjan, 2018b). It will illustrate the enormous responsibility in conveying the results got by students as input for the school, students, and their parents (Nurjan, 2018a). Here, of course, it must be followed by clear objectives and parameters in an assessment conducted by the teacher to map the intellectual condition, talents and creativity, personality, and motivation of students in the school (Fachruddin, 2017).

Based on the results of interviews with teachers and school counselors; and observations, that the development of giftedness of students at MI Pesantren Anak Sholeh Baitul Qur'an Gontor Ponorogo varies, some are talented in the arts, futsal, scouts, drum bands, sports, tambourine arts, and are academically talented, and increase with additional special hours grouped with a special class (tahfidz class Qur'an). This is in line with Idris (2017), which requires the development of giftedness of students to be proven by high achievement abilities in fields such as intellectual, creative, artistic, leadership, or specific academic capacities, and requires services or activities that are not the same as those provided. in school in connection with the discovery of his abilities (Ozcan \& Uzunboylu, 2019).

In addition, gifted behavior and morals of students at the Islamic Boarding School for Children Sholeh Baitul Qur'an Gontor Ponorogo, has become a separate icon, namely: dhuha prayer in congregation, dzuhur prayer in congregation, Friday prayer in congregation, recitation, recitation of the Qur'an, throwing trash in its place, and so on. All elements handle the giftedness of their respective students, especially the principal and vice-principal of student affairs, who organize and accompany the giftedness of the students of MI Pesantren Anak Sholeh Baitul Qur'an Gontor Ponorogo.

According to Nurjan (2018a), gifted students must get good educational services, and in effect also refer to the assumption that giftedness has strong implications for the emergence of certain characteristics, needs, and problems that are relatively different from normal children. Gifted children have different needs from other children in various aspects of development or life (Andesta, 2018), both in mental health, self-development, cognitive development, achievement, academics, and future careers (Anggraini et al., 2020; Mönks \& Mason, 2000).

The development of giftedness of students at MI Pesantren Anak Sholeh Baitul Qur'an Gontor Ponorogo can be seen by knowing early on the gifted development of students through academic scores and using a certain value rating, and grouped through the distribution of questionnaires. This is in line with Wang \& Tsai (2016), which requires the ability of students to work on their own to achieve something that has been planned, a powerful will, perseverance, and a strong effort in trying to achieve notable achievement. 
In addition, the development of giftedness of students at MI Pesantren Anak Sholeh Baitul Qur'an Gontor Ponorogo is not only related to academics, although schools do not facilitate non-academic giftedness. The effort of MI Pesantren Anak Sholeh Baitul Qur'an Gontor Ponorogo for this is very large, with its limitations trying to accommodate it by bringing in jujitsu art tutors, drum bands, qiro 'ah, tambourine, futsal, and various other gifts. Meanwhile, the development of giftedness of the students of MI Pesantren Anak Sholeh Baitul Qur' an Gontor Ponorogo in the religious field is more prominent, as Tahfidzul Qur'an and Islamic culture as greetings, dhuha prayer, recitation, other Islamic habits. As for the development of mathematical academic talent by inviting tutors through enrichment programs.

The commitment of gifted students at MI Pesantren Anak Sholeh Baitul Qur'an Gontor Ponorogo to school tasks is as disciplined, and students are required to follow and carry out the tasks assigned to them. The form of high creativity of talented students is their participation in drum band competitions, scout competitions, tambourine art competitions, sports competitions, speech competitions, and other competitions. And this is inseparable from the support of teachers to gifted students by motivating them as a teacher helps them at every competition event. The teacher helps gifted students through certain subjects outside of school hours, with the knowledge of their respective homeroom teachers.

However, school facilities have not been maximal in providing facilities for gifted students, for example, various extracurricular spaces that are still incorporated in the study room. Then in teaching and learning activities, the teacher prepares special classes for gifted students by adding learning hours from regular classes. Every teaching and learning activity is designed with the formation of talents, especially gifted behavior and morals, such as instilling a strong diversity for students when entering lessons by reading prayers, and then every lesson change is always preceded by bismillah by the teacher. The holders of commitment in developing the talents of students at MI Pesantren Anak Sholeh Baitul Qur'an Gontor Ponorogo are all elements, but the more dominant is the deputy principals and assisted by the deputy principal in the curriculum and other teachers.

The talent development of students at the Islamic Islamic Boarding School Sholeh Baitul Qur'an Gontor Ponorogo cannot be separated from the role of the family in providing facilities, assistance, encouragement, and motivation to gifted children in carrying out their duties such as school fees, school assignments from home and other tasks. Knowing children's talents, parents can ask questions and observe children's activities.

Based on this, the development of giftedness of the students at MI Pesantren Anak Sholeh Baitul Qur'an Gontor Ponorogo who is guided directly by parents has a firm commitment to developing the giftedness of students at home and in their environment. As for gifted behavior/morals, it can be said to be good. The development of student talents must coincide with the character building and discipline of children (Ersoy \& Uysal, 2019; Tahrir, 2009), to find out existing abilities and need to be improved (Maghfiroh et al., 2019).

Gifted children at MI Pesantren Anak Sholeh Baitul Qur'an Gontor Ponorogo stated that their relationships and ways of socializing are no different from other children, but they appear to be different in their appearance. Gifted children at MI Pesantren Anak Sholeh Baitul Qur'an Gontor Ponorogo stated that their relationships and ways of socializing are no different from other children, but they appear to be different in their appearance. The learning time for gifted students is done in the morning before leaving for school, and at night, with more time duration than other students.

Some of the gifted students at the MI Pesantren Anak Sholeh Baitul Qur'an Gontor Ponorogo have more grades than others, and some others have intelligence above average. This is in line with Ozcan \& Uzunboylu (2019) and Renzulli (1992), that gifted students have a firm commitment, namely completing the tasks given to them well, even completing the 
task earlier than other friends. When viewed from how to get along with students who are to be given the same as others, they only hang out with the same sex.

As for the forms of giftedness possessed by talented students at the Sholeh Baitul Qur'an Gontor Ponorogo Islamic Boarding School, such as having achievements in drum band activities, muhadhorah, tambourine, futsal, scouting, sports, badminton, and so on. And those who play the most role in delivering talented students are family, teachers, friends, and Allah SWT. Gifted students can manage time, namely the time to develop their talents and time to make friends, and the ability to maintain a balance between learning and socializing. Peers support gifted students who are marked with pride in their achievements, want to imitate and follow them, and some others are not supportive because every student develops their talents. Based on these results, it can be understood that guidance and counseling services in elementary schools have a positive impact on students, specifically they can provide opportunities for students to develop their potential, interests, be able to recognize themselves and their environment, be able to direct themselves and be able to solve the problems they face optimally.

\section{Conclusions and Suggestions}

The development of giftedness of elementary education students at the Islamic Boarding School for Children Sholeh Baitul Qur'an Gontor Ponorogo is closely related to the concept of three rings of gifted development of students put forward by Renzulli, including: First, show above-average abilities, namely: (1) general ability, which comprises: a high level of abstract thinking, verbal and numerical reasoning, spatial relationships, memory, fluency; adaptation to and formation of new situations in the external environment; and information processing automation; and (2) special abilities, which comprise: the application of various combinations of general abilities above to more specific fields (such as mathematics, science, arts, leadership), and the ability to gain and appropriately use some formal knowledge, techniques, and strategies for solving specific problems.

Second, shows a commitment to the task, namely: the high ability to interest, enthusiasm, and involvement with a particular problem or field; perseverance, endurance, determination, hard work, and devotion; self-confidence, belief, and a strong desire to achieve; the ability to identify problems in certain areas; and maintaining self-disclosure and external criticism; develop a sense of aesthetics, quality, and excellence about his work and the work of others. Third, showing high creativity, namely: fluency, flexibility, and authenticity in thinking; openness to experience; receptive to what is different in one's own and others' thoughts, actions, and products; curious, speculative, and adventurous, the desire to take risks in both thoughts and actions; sensitive to the characteristics of ideas and something detailed and aesthetic; the desire to act and react to external stimulation, their ideas and feelings, and the courage to continue achieving. Based on these results, it can be understood that guidance and counseling services in elementary schools have a positive impact on students. The results of the research are expected to provide inspiration for principals, teachers, and counselors to apply the gifted student method to guidance and counseling services because it can provide opportunities for students to develop optimally according to their potential and interests. Able to make themselves and their environment able to direct themselves alone; and able to solve the problems it faces.

\section{References}

Al-Bukhari, A. A. M. bin I. (2011). Ensiklopedia Hadits: Shahih al-Buhhari (Terj. Masyhar dan Muhammad Suhadi (ed.)). Jakarta: Almahira.

Andesta, D. (2018). Analisis kebutuhan anak usia dasar dan Implikasinya dalam 
penyelenggaraan pendidikan. JIP (Jurnal Ilmiah PGMI), 4(1), 82-97.

Anggraini, K. C. S., Sudana, I. N. D., Kuswandi, D., \& Setyosari, P. (2020). Effect of Guided Inquiry Learning Model and Social Skills to the Improving of Students' Analysis Skills in Social Studies Learning. Journal for the Education of Gifted Young Scientists, 8(1), 603-622.

Aulia, D. (2020). Efektivitas Layanan Bimbingan Kelompok dengan Teknik Self Management untuk Meningkatkan Perilaku Menjaga Kebersihan Sekolah pada Siswa Kelas VIII SMP Negeri 25 Banjarmasin. Jurnal Pelayanan Bimbingan Dan Konseling, 3(2).

Ersoy, E., \& Uysal, R. (2019). Opinions of school psychological counselors on giftedness and gifted students' education. American Journal of Qualitative Research, 2(2), 120-142.

Fachruddin, F. (2017). Pengembangan Daya Kreatif (Creative Power) Melalui Dunia Sekolah: Identifikasi Isu. Sukma: Jurnal Pendidikan, 1(1), 131-175.

Fadhli, M., Sukirman, S., Ulfa, S., Susanto, H., \& Syam, A. R. (2019). Gamifying Children's Linguistic Intelligence With the Duolingo App. https://doi.org/10.4018/978-1-79981486-3.ch007

Hava, K., Guyer, T., \& Cakir, H. (2020). Gifted students' learning experiences in systematic game development process in after-school activities. Educational Technology Research and Development, 1-21.

Idris, M. H. (2017). Anak Berbakat (Keberbakatan). Permata: Jurnal Pendidikan Anak Usia Dini, 2(1), 35-50.

Klimecká, E. (2020). Labelling of gifted children in the family from the perspective of teachers and its manifestations at school. Sodobna Pedagogika, 71(2), 196-212.

Laine, S., \& Tirri, K. (2016). How Finnish elementary school teachers meet the needs of their gifted students. High Ability Studies, 27(2), 149-164.

Lee, B., \& Son, J. (2017). Exploring the Improvement Plan for Science-Gifted Education through Analysis of the Performance Result of Master plan for Identifying and Nurturing of Science-Gifted Student. Journal of The Korean Association For Science Education, 37(5), 775-785.

Maghfiroh, F., Sholikhah, H. A., \& Sofyan, F. A. (2019). Upaya Guru dalam Mengatasi Kesulitan Belajar Membaca Siswa. JIP (Jurnal Ilmiah PGMI), 5(1), 95-105.

Miles, M. B., Huberman, A. M., \& Saldaña, J. (2014). Qualitative Data Analysis: A Methods Sourcebook. Thousand Oaks, CA: Sage.

Miller, G. (2014). Learning the language of addiction counselling. New Jersey: John Wiley $\&$ Sons.

Mönks, F. J., \& Mason, E. J. (2000). Developmental Psychology and Giftedness: Theories. International Handbook of Giftedness and Talent, 141.

Munandar, U. (2012). Pengembangan Kreativitas pada Anak Berbakat. Jakarta PT. Rineka Cipta.

Nurjan, S. (2018a). Analisis Teoritik Keberbakatan Siswa. AL-ASASIYYA: Journal Of Basic Education, 2(2).

Nurjan, S. (2018b). Pengembangan Berpikir Kreatif. AL-ASASIYYA: Journal Of Basic Education, 3(1), 105-116.

Ozcan, D., \& Uzunboylu, H. (2019). School counsellors' perceptions of working with gifted students. South African Journal of Education, 40(1), S1--S9.

Pietrofesa, J. J., Leonard, G. E., \& Van Hoose, W. (1971). The authentic counselor. Chicago: Rand McNally.

Renzulli, J. S. (1992). A General Theory for the Development of Creative Productivity Through the Pursuit of Ideal Acts of Learning1. Gifted Child Quarterly, 36(4), 170182. 
Renzulli, J. S. (2016). The three-ring conception of giftedness: A developmental model for promoting creative productivity. Prufrock Press.

Rimonda, R., Wibowo, M. E., \& Jafar, M. (2018). The effectiveness of group counselling by using cognitive behavioral therapy approach with cinematherapy and self-talk techniques to reduce social anxiety at SMK N 2 Semarang. Jurnal Bimbingan Konseling, 7(2), 145-152.

Sendayu, F. S., \& Sunaryo, S. A. (2020). Cultural intelligence model based on value "pintar tuntang harati" for growing peace in senior high school students in Palangka Raya City. AL-ASASIYYA: Journal Of Basic Education, 4(2), 151-160.

Sugiyono, S. (2015). Metode Penelitian \& Pengembangan (Research and Development). In Bandung: Alfabeta.

Syafril, S., Yaumas, N. E., Ishak, N. M., Yusof, R., Jaafar, A., Yunus, M. M., \& Sugiharta, I. (2020). Characteristics and educational needs of gifted young scientists: a focus group study. Journal for the Education of Gifted Young Scientists, 8(2), 947-954.

Tahrir, T. (2009). Pola Pengembangan Keberbakatan Dan Pembentukan Kedisiplinan Anak. Psympathic: Jurnal Ilmiah Psikologi, 1(1), 39-50.

Thahir, A., \& Hidayat, R. (2020). The concept of human personality al-Ghazali and sigmund freud in counselling perspectives. KONSELI: Jurnal Bimbingan Dan Konseling (EJournal), 7(1), 61-72.

Tresnawaty, Y. (2015). Pengaruh penyesuaian diri sosial dengan perilaku agresif anak berbakat intelektual. Jurnal Ilmiah Penelitian Psikologi: Kajian Empiris \& NonEmpiris, 1(1).

Ulfatin, N. (2015). Metode Penelitian Kualitatif di Bidang Pendidikan: Teori dan Aplikasinya. Malang: Media Nusa Creative.

Wang, Y.-L., \& Tsai, C.-C. (2016). Taiwanese students' science learning self-efficacy and teacher and student science hardiness: A multilevel model approach. European Journal of Psychology of Education, 31(4), 537-555.

Yaman, D. Y., \& Sökmez, A. B. (2020). A case study on social-emotional problems in gifted children. Elementary Education Online, 19(3), 1768-1780.

Yoenanto, N. H. (2012). Hubungan antara self-regulated learning dengan selfefficacy pada siswa akselerasi sekolah menengah pertama di Jawa Timur. Jurnal Insan Media Psikologi, 12(2).

Zeidner, M., \& Matthews, G. (2017). Emotional intelligence in gifted students. Gifted Education International, 33(2), 163-182. 
